\title{
WIELORAKA RÓWNOWAGA W NEOKEYNESOWSKICH MODELACH NIECENOWYCH BŁĘDÓW KOORDYNACJI
}

\section{WSTEP}

Program badawczy neokeynesizmu, powstałego na początku lat 70. XX w., jest niezwykle heterogeniczny i obejmuje swym zasięgiem wiele różnorodnych zjawisk i problemów. Jednym z nich jest możliwość pojawiania się w gospodarce rynkowej wielu równowag, odmiennych pod względem stopnia wykorzystania czynników produkcji. Bezpośrednią przyczyną wielorakiej równowagi jest brak możliwości zsynchronizowania na szczeblu centralnym wszystkich decyzji podejmowanych indywidualnie przez racjonalne podmioty. W rezultacie gospodarka o danym zasobie czynników wytwórczych wykazuje szereg potencjalnych, równie prawdopodobnych stanów równowagi, które można uszeregować według kryterium Pareto-optymalności.

Neokeynesowskie badania nad błędami koordynacji generującymi wieloraką równowage podążają w dwóch zasadniczych kierunkach. Pierwszy koncentruje się na nieskoordynowanych pojedynczych dostosowaniach cen nominalnych w warunkach niedoskonale konkurencyjnej gospodarki ${ }^{1}$. W zależności od tego, jak wielu przedsiębiorców podejmie decyzję o usztywnieniu swej ceny nominalnej w reakcji na obserwowany szok oraz na jakim poziomie ukształtuje się sztywna cena zagregowana, system osiągnie równowagę o określonym poziomie aktywności gospodarczej. Zgodnie z drugim kierunkiem badań, problemów z koordynacją działań poszukuje się po stronie realnej (produkcji i wymiany) wysoce zróżnicowanej i zdecentralizowanej gospodarki rynkowej². Stopień elastyczności cen (i płac) nie ma tu żadnego znaczenia dla powstawania i nasilania błędów koordynacji, a tym samym dla generowania wielorakiej równowagi.

${ }^{1}$ G. A. Akerlof, J. L. Yellen, A Near-Rational Model of the Business Cycle, with Wage and Price Inertia, „Quarterly Journal of Economics” 100, 1985, nr 4, Supplement; N. G. Mankiw, Small Menu Costs and Large Business Cycles: A Macroeconomic Model of Monopoly, „Quarterly Journal of Economics” 100, 1985, nr 2; O. J. Blanchard, N. Kiyotaki, Monopolistic Competition and the Effects of Aggregate Demand, „American Economic Review” 77, 1987, nr 4.

${ }^{2}$ P. A. Diamond, Aggregate Demand Management in Search Equilibrium, „Journal of Political Economy" 90, 1982, nr 5; M. Weitzman, Increasing Returns and the Foundations of Unemployment Theory, ,Economic Journal” 92, 1982, nr 368; G. Woglom, Underemployment Equilibrium with Rational Expectations, ,QQuarterly Journal of Economics” 97, 1982, nr 1; J. Bryant, A Simple Rational Expectations Keynes-Type Model, „Quarterly Journal of Economics” 98, 1983, nr 3; N. Kiyotaki, Multiple Expectational Equilibria under Monopolistic Competition, ,Quarterly Journal of Economics” 103, 1988, nr 4. 
W artykule skupiono się na istocie neokeynesowskich modeli niecenowych błędów koordynacji, ze szczególnym uwzględnieniem ich powiązań z Ogólna teoria zatrudnienia, procentu i pieniadza Johna M. Keynesa ${ }^{3}$. W części drugiej omówiono zasadniczą strukturę modeli niecenowych błędów koordynacji, akcentując przede wszystkim rolę strategicznej komplementarności, oczekiwań oraz giętkości cen i płac nominalnych dla pojawiania się wielu stanów równowagi. W części trzeciej - ze względu na ich silne bezpośrednie odniesienia do poglądów Keynesa zaprezentowanych w Ogólnej teorii - neokeynesowskie modele niecenowych błędów koordynacji przedstawiono jako trzon paradygmatu keynesowskiego. Natomiast część czwartą poświęcono ocenie tych własności modeli wielorakiej równowagi, które budzą na tyle duże kontrowersje, że pozwalaja na zakwestionowanie ich keynesowskiej proweniencji. $\mathrm{W}$ zakończeniu zawarto uwagi i wnioski płynące $\mathrm{z}$ dokonanej $\mathrm{w}$ artykule analizy.

\section{STRATEGICZNA KOMPLEMENTARNOŚĆ, „ZWIERZĘCE INSTYNKTY” I WIELORAKA RÓWNOWAGA}

Istotą modeli błędów koordynacji jest to, że w gospodarce ustala się równowaga $\mathrm{z}$ niepełnym wykorzystaniem czynników produkcji (Pareto-podrzędna), mimo iż równowaga lepsza (Pareto-nadrzędna) istnieje i jest możliwa do osiągnięcia. W zdecentralizowanym systemie, w którym nie ma wszechwiedzącego walrasowskiego licytatora ustalającego ceny i ilości równowagi, podmioty są zmuszone podejmować decyzje suwerennie, nie mając pełnej wiedzy na temat zachowania pozostałych uczestników rynku. Jednostki, choć sa racjonalne, działaja zatem $\mathrm{w}$ warunkach niedoskonałej informacji. W swoich wyborach ekonomicznych kierują się wyobrażeniami co do przyszłości i bieżącego zachowania pozostałych podmiotów. Antycypując interakcje zachodzące między podmiotami, sektorami i okresami, jednostki wpływają równocześnie na ich realizację, co sprawia, że w równowadze prognozy nabieraja charakteru samospełniającego się. Innymi słowy, równowaga rynkowa jest funkcją oczekiwań, keynesowskich „zwierzęcych instynktów” determinujących sposób postępowania uczestników wymiany handlowej. Gospodarka o danym zasobie czynników produkcji może więc wykazywać wiele różnych stopni ich faktycznego wykorzystania w zależności od tego, jak kształtują się oczekiwania podmiotów co do najbliższej przyszłości. Gdy już dojdzie do ustalenia określonej równowagi, wówczas ze względu na ogólny stan nastrojów społecznych racjonalne podmioty nie będą wykazywać żadnego bodźca do zmiany swojego postępowania. Jeżeli gospodarka „utknie” w równowadze z niskim stopniem wykorzystania czynników produkcji, może w niej trwale pozostawać, nawet jeśli równowaga lepsza (z pełnym zatrudnieniem) istnieje.

Konsekwencją uzależnienia stanu równowagi od ,,zwierzęcych instynktów” podmiotów jest pojawienie się continuum równowag, które różnią się między

${ }^{3}$ J. M. Keynes, The General Theory of Employment, Interest and Money, Macmillan, London 1936 (wyd. pol. Ogólna teoria zatrudnienia, procentu i pieniadza, WN PWN, Warszawa 2003). 
sobą o (poprawny przy danym zbiorze informacji) stan oczekiwań i które można uszeregować pod względem Pareto-optymalności. Faza recesji jest spowodowana brakiem koordynacji różnego rodzaju działań podmiotów w kierunku osiagnnięcia poprawy sytuacji i przesunięcia systemu do lepszej równowagi. Te działania mogą dotyczyć każdego aspektu gospodarowania - ustaleń cenowych i płacowych, procedur zatrudniania pracowników i nabywania dóbr, technologii produkcji i wymiany, sposobów poszukiwania miejsc pracy, siły roboczej i partnerów handlowych i tak dalej. Stąd wniosek, że brak synchronizacji decyzji cenowo-płacowych nie jest warunkiem koniecznym do pojawienia się zjawiska wielorakiej równowagi. Oczywiście, moga pojawić się bariery w dostosowaniach cenowych. Nie stanowią one jednak bezpośredniej przyczyny fluktuacji gospodarczych, lecz są konsekwencją braku synchronizacji indywidualnych decyzji dotyczących produkcji i wymiany, czyli sfery niecenowej (realnej). W wielu neokeynesowskich modelach niecenowych błędów koordynacji dowodzi się, że sztywność nominalna cen i płac nie tylko nie stanowi fundamentalnego problemu, ale jest środkiem skutecznie powstrzymującym gospodarkę przed przesunięciem do gorszej równowagi.

Kluczową kwestią w niecenowych modelach błędów koordynacji jest strategiczna komplementarność ${ }^{4}$. Polega ona na tym, że określone zachowanie jednych podmiotów skłania pozostałe do podobnych działań, wywołując $\mathrm{w}$ ten sposób mnożnikowe wzmocnienie początkowego zakłócenia (spadku lub wzrostu aktywności gospodarczej). W rezultacie, nawet niewielki szok, jeżeli pociagnie za sobą powszechna zmianę oczekiwań i faktycznych zachowań, prowadzi do poważnych trwałych wahań koniunktury. Taki mnożnikowi efekt może mieć swe źródło w działalności handlowej ${ }^{5}$, produkcyjnej $^{6}$ lub inwestycyjnej ${ }^{7}$.

W modelu Diamonda strategiczna komplementarność wiąże się z efektami zewnętrznymi ,,tłustych” i ,,chudych” rynków ${ }^{8}$. W okresach ożywienia gospodarczego podmioty nie maja żadnych problemów ze znalezieniem partnera handlowego, dzięki czemu koszty poszukiwań i wzajemnego dopasowania zarówno po stronie popytowej, jak i podażowej sa niskie. Wzrost aktywności gospodarczej jednego podmiotu obniża koszty marginalne zawierania transakcji u partnera handlowego, który dzięki temu zwiększa swój wysiłek. Odwrotna tendencja ma miejsce $\mathrm{w}$ okresach recesji, kiedy to podmioty nie sa skłonne do intensyfikowania swych działań. W rezultacie, koszty transakcyjne rosna jeszcze bardziej, utrwalając tendencje depresyjne. Spadek aktywności w działalności handlowej pociaga za soba obniżenie poziomu produkcji i zatrudnienia, a im poważniejsze jest obniżenie koniunktury, tym trudniejsze i droższe staje się znalezienie kontrahenta lub pracownika. Egzogeniczne ograniczenie rynkowe sprawia, że zarówno producenci, jak i pracownicy działają niedobrowolnie. Chociaż pierwsi chcieliby wytwarzać i sprzedawać więcej, a drudzy więcej

${ }^{4}$ Pojęcie strategicznej komplementarności (jak również strategicznej substytucyjności) wprowadzili J. I. Bulow, J. D. Geanakoplos, P. D. Klemperer, Multimarket Oligopoly: Strategic Substitutes and Complements, ,„Journal of Political Economy” 93, 1985, nr 3.

${ }^{5}$ P. A. Diamond, op. cit.

6 J. Bryant, op. cit.

${ }^{7}$ N. Kiyotaki, op. cit.

${ }^{8}$ P. A. Diamond, op. cit. 
pracować, to żaden podmiot nie wykazuje skłonności do zmiany swojego postępowania wobec założonej z góry bezczynności pozostałych jednostek.

Niepełne wykorzystanie czynników produkcji pojawia się pomimo to, że podmioty w modelu Diamonda sa racjonalne i homogeniczne, a ceny i płace doskonale elastyczne. Pierwszoplanowym problemem jest tu bowiem stochastyczny charakter procesu poszukiwań i dopasowań w zdecentralizowanej gospodarce, w której nie ma doskonałej informacji. Ustalenie określonej równowagi - Pareto-nadrzędnej lub Pareto-podrzędnej - zależy bezpośrednio od stanu oczekiwań podmiotów. Prognozy decydują o poziomie indywidualnego wysiłku, co z kolei wpływa na zachowanie pozostałych uczestników rynku. W tej sytuacji uelastycznianie cen (i płac) nie przyniesie żadnych pozytywnych rezultatów. Problemem nie są tu bowiem niewłaściwie ustalone poziomy cen, lecz zbyt wysokie koszty poszukiwań i dostosowań strony popytowej i podażowej. Jedynym sposobem na osiągnięcie lepszej równowagi, w której każdy podmiot odczułby poprawę swej sytuacji, byłoby dostarczenie bodźca do zmiany panujących powszechnie pesymistycznych oczekiwań. Ponieważ w gospodarce nie istnieje mechanizm doprowadzajacy do takiej skoordynowanej zmiany w nastrojach społecznych, stan depresji nabiera cech trwałości.

Diamond sugerował, że polepszeniu sytuacji mogłaby służyć polityka gospodarcza, zwłaszcza subsydia produkcji, finansowane z podatków obciążających w równym stopniu zatrudnionych i bezrobotnych. Z takim rozwiązaniem wiążą się jednak dwie podstawowe trudności. Po pierwsze, rząd, chcąc obniżyć koszty wytwarzania i zwiększyć produkcję i zatrudnienie, musiałby mieć możliwość kontrolowania decyzji produkcyjnych wszystkich prywatnych podmiotów. Po drugie, władze musiałyby posiadać wiedzę na temat stanu i sposobu formowania oczekiwań przez podmioty, by odpowiednio zaprojektować narzędzia wywierające pożądany wpływ na zmianę zachowań uczestników rynku.

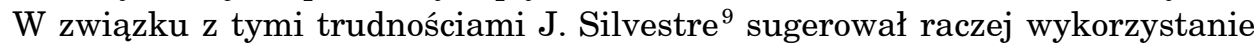
polityki monetarnej jako sygnału informującego o zbliżającej się zmianie warunków gospodarowania. W równowadze Pareto-podrzędnej żadnemu z podmiotów nie opłaca się wydatkować wysiłku, ale równocześnie każdy z nich zmieniłby swoje postępowanie, gdyby tylko poziom zagregowanej aktywności wzrósł. Ekspansywna polityka monetarna mogłaby posłużyć jako zapowiedź ożywienia, wpływając pozytywnie na oczekiwania jednostek.

Podobny tok rozumowania leży u podstaw modelu strategicznej komplementarności w działalności produkcyjnej J. Bryanta ${ }^{10}$, w którym pojawia się continuum równowag $\mathrm{z}$ racjonalnymi oczekiwaniami i niepełną informacją. Ustalenie równowagi Pareto-podrzędnej jest całkowicie niezależne od prowadzonej polityki monetarnej, systemu finansowego i struktury cenowej. Problem tkwi tu bowiem w trudnościach ze skoordynowaniem na szczeblu zagregowanym wysoce wyspecjalizowanego, wieloetapowego i zdecentralizowanego procesu produkcji. W rezultacie, ,zwierzęce instynkty”, poprzez efekty mnożnikowe, moga doprowadzić do osiagnięcia równowagi zdominowanej przez pesymistyczne nastroje oraz niskie wskaźniki gospodarcze.

${ }^{9}$ J. Silvestre, The Market-Power Foundations of Macroeconomic Policy, ,Journal of Economic Literature" 31, 1993, nr 1.

10 J. Bryant, op. cit. 
N. Kiyotaki z kolei zbudował model, w którym wieloraka równowaga jest wynikiem interakcji stanu długookresowych racjonalnych oczekiwań monopolistycznie konkurencyjnych firm i ich decyzji inwestycyjnych ${ }^{11}$. W gospodarce, w której wielu producentów dostarcza zróżnicowanych dóbr, zapotrzebowanie na wyroby danej firmy maleje wraz ze wzrostem ceny, a położenie indywidualnej krzywej popytu zależy od zagregowanego popytu. Bieżące decyzje inwestycyjne firmy są oparte na jej prognozach dotyczących przyszłego popytu. Równocześnie produkcja równowagi w przyszłości jest funkcją przyszłego zasobu kapitału, który z kolei zależy od bieżących inwestycji. Przy założeniu, że technologia produkcji generuje rosnące efekty skali, a zagregowana podaż pracy jest do pewnego poziomu elastyczna, w gospodarce może się pojawić wieloraka równowaga. To, która równowaga zostanie rzeczywiście osiągnięta, zależy od stanu oczekiwań racjonalnych firm, technologii produkcji oraz gustów i preferencji. Jeżeli firmy optymistycznie antycypuja przyszły popyt, to będą aktywnie inwestować. Zasób kapitału wzrośnie, a poziom produkcji w równowadze będzie wysoki. Pozytywne nastroje okażą się samospełniające. W odwrotnej sytuacji, gdy firmy inwestuja niewiele $\mathrm{z}$ powodu pesymistycznych oczekiwań, zasób kapitału i poziom produkcji w równowadze ukształtują się na niskich poziomach. Według N. Kiyotakiego, jeżeli gospodarka osiądzie w równowadze Pareto-podrzędnej, sytuację może poprawić jedynie rządowa polityka subsydiowania inwestycji, dzięki której firmy zmienią swe oczekiwania z pesymistycznych na optymistyczne.

W wyżej opisanych modelach błędy koordynacji i równowaga Pareto-podrzędna pojawiały się bez względu na zachowanie cen. P. A. Diamond przyjął explicite doskonała elastyczność cen, N. Kiyotaki dla uproszczenia założył, że ceny sa dane, a u J. Bryanta ceny nie odgrywaja żadnej roli $\mathrm{w}$ wywodzie formalnym. Związek między błędami koordynacji i wieloraka równowaga a stopniem elastyczności cen przeanalizował bardziej szczegółowo G. Woglom ${ }^{12}$. Wykorzystując koncepcję załamanej krzywej popytu na rynku dóbr, autor wykazał, że konsekwencja braku synchronizacji decyzji gospodarczych podmiotów może być sztywność nominalna cen ${ }^{13}$. Nie jest to jednak przyczyna trwałego obniżenia koniunktury, lecz racjonalna wtórna reakcja podmiotów na niecenowe błędy koordynacji obserwowane w warunkach niedoskonałej informacji. Woglom dowiódł, że nawet jeśli firmy zachowuja się optymalnie, a konsumenci formuja oczekiwania racjonalnie, najlepsza równowaga może nie zostać wybrana. Jeżeli konsumenci będą przekonani, że w równowadze żadna $\mathrm{z}$ firm nie zmieni swojej ceny tak, by wpłynąć na poziom zagregowanego popytu, to oczekiwany poziom cen będzie równy dotychczasowemu, przy którym występuje załamanie (nieciagłość) krzywej popytu. W rezultacie firmy nie będa miały żadnego bodźca do tego, by zmienić ceny i osiągnąc równowagę Pareto-nadrzędną. Według G. Wogloma, dopóki krzywa kosztu marginalnego przecina krzywa przychodu marginalnego na

\footnotetext{
${ }^{11}$ N. Kiyotaki, op. cit.

12 G. Woglom, op. cit.

${ }^{13}$ T. Negishi, Microeconomic Foundations of Keynesian Macroeconomics, North-Holland Publishing Company, Amsterdam 1979.
} 
jej nieciągłym odcinku, osiągnięcie najlepszej równowagi będzie niemożliwe. Prognozy konsumentów, zgodnie z którymi obowiązujący poziom cen, przy którym popyt się załamuje, nie ulegnie zmianie, prowadzą do ustalenia równowagi gorszej od najlepszej możliwej. Firmy mogłyby poprawić sytuację tylko wtedy, gdyby zawarły powszechne porozumienie synchronizujace ich zachowanie w skali makroekonomicznej. Taka umowa musiałaby zagwarantować każdej firmie, że wprowadzone zmiany cen nie zaburza ich dotychczasowej struktury. W zdecentralizowanej gospodarce takie rozwiązanie jest oczywiście niemożliwe do wprowadzenia w życie. Stąd żadna firma nie podejmie działań w kierunku dostosowań cenowych, obawiając się, że skorzystają na tym pozostałe przedsiębiorstwa, które utrzymaja swe ceny na obowiązujących poziomach. Bodźcem do pokonania tej niekorzystnej sytuacji może być wyłącznie polityka monetarna. W opinii G. Wogloma, impuls monetarny zwiększy popyt zagregowany i przesunie system do równowagi Pareto-nadrzędnej nawet wtedy, gdy będzie całkowicie przewidziany. Jego wpływ opiera się bowiem nie na zaskoczeniu, ale na poprawie nastrojów wszystkich uczestników rynku.

Podczas gdy G. Woglom dowodził, że sztywność cen jest naturalną reakcja racjonalnych firm na brak możliwości skoordynowania indywidualnych działań w kierunku jednolitych dostosowan, M. Weitzman ${ }^{14}$ poszedł o krok dalej, sugerując, że taka sztywność jest w stanie uchronić niedoskonale konkurencyjna gospodarkę od utknięcia w gorszej równowadze. M. Weitzman zbudował model równowagi ogólnej, koncentrując się na mechanizmie powstawania zjawiska przymusowego bezrobocia. Jego przyczyną sa, według autora, rosnące efekty skali produkcji, które powoduja, że podaż przestaje sobie stwarzać popyt. W zdecentralizowanej gospodarce rynkowej firmy specjalizują się w wytwarzaniu jednego konkretnego dobra, podczas gdy ich pracownicy za otrzymane wynagrodzenie nabywają wiele produktów oferowanych przez liczne firmy na rynku. W sytuacji spadku zagregowanego popytu firmy nie zwiększaja zatrudnienia, obawiając się, że nie będa $\mathrm{w}$ stanie zyskownie sprzedać na lokalnym rynku dodatkowej wielkości produkcji wytworzonej przez nowego pracownika. Bezrobocie oznacza natomiast spadek produkcji i konsumpcji, co trwale podtrzymuje niższy poziom zatrudnienia. Prognozy racjonalnych podmiotów doprowadzają do określonego poziomu przymusowego bezrobocia, który - o ile jest stabilny - oznacza równowagę rynkową. Pojedyncza firma nie jest $\mathrm{w}$ stanie zaradzić tej sytuacji. Jedynym wyjściem staje się koordynacja działań w skali makroekonomicznej, dostarczająca impulsu do równoczesnego zwiększenia produkcji na wszystkich rynkach. Natomiast mechanizm cenowy nie jest w stanie wywrzeć pozytywnych efektów. M. Weitzman wykazał, że nawet gdyby udało się doprowadzić do powszechnego spadku płac realnych droga cięć wielkości nominalnych, to efektem byłby nie tylko brak spadku poziomu bezrobocia przymusowego w równowadze, ale wręcz jego wzrost. Chociaż spadek płac realnych skłoniłby firmy do zwiększenia zatrudnienia, to ta pozytywna tendencja zostałaby zneutralizowana spadkiem popytu na rynku dóbr spowodowanym ograniczeniem dochodów konsumentów. Stąd wniosek, że

${ }^{14}$ M. Weitzman, op. cit. 
w obliczu strategicznej komplementarności sztywność cen i płac zapobiega przesuwaniu się systemu do równowagi z jeszcze niższymi wskaźnikami gospodarczymi.

Również H. Bohn i G. Gorton ${ }^{15}$, włączając do analizy nominalne kontrakty płacowe, dowiedli, że sztywności nominalne cen prowadzą do osiągnięcia równowagi Pareto-nadrzędnej $\mathrm{w}$ stosunku do równowagi $\mathrm{z}$ doskonale elastycznymi cenami. Zdaniem autorów, powszechność zjawiska podpisywania kontraktów płacowych można uzasadnić właśnie tym, że gwarantują one poprawę w sensie Pareto $\mathrm{w}$ systemie zdominowanym przez błędy koordynacji. Podobnie K. Mischel ${ }^{16}$ wykazał, że sztywności nominalne cen należy uznać raczej za sukces niż błąd koordynacji. Przedstawił on prosty model, w którym przedsiębiorcy pozyskuja informacje o stochastycznych zmianach popytu po określonym dodatnim koszcie. Równowaga ze sztywnościami nominalnymi cen okazuje się wtedy Pareto-nadrzędna względem równowagi odznaczającej się elastycznymi cenami.

\section{NIECENOWE BŁEDDY KOORDYNACJI JAKO KONSTRUKCJE O CHARAKTERZE KEYNESOWSKIM}

Modele niecenowych błędów koordynacji wykazują wiele takich cech, których korzenie można odnaleźć w Ogólnej teorii. Jedną z nich jest bez wątpienia wykorzystanie metody równowagi ogólnej, akcentującej kwestię współzależności rynkowych. Konstrukcje teoretyczne dotyczące błędów koordynacji opieraja się na zjawisku strategicznej komplementarności, interakcjach między podmiotami, sektorami i okresami, synergii oraz efektach zwrotnych, dających podstawy do wszechstronnej analizy całego systemu gospodarczego, a nie tylko jego wyizolowanych części ${ }^{17}$. Doskonałym tego przykładem jest model M. Weitzmana ${ }^{18}$, w którym zakłócenie na rynku dóbr (spadek popytu efektywnego pod wpływem pesymistycznych prognoz) doprowadza do powstania trwałego przymusowego bezrobocia na rynku pracy. Cały system pozostaje $\mathrm{w}$ równowadze $\mathrm{z}$ niskimi wskaźnikami gospodarczymi, nie wykazując żadnej samoistnej tendencji do poprawy sytuacji. Ten sposób modelowania zachowań gospodarki rynkowej stanowi powrót do oryginalnej idei J. M. Keynesa, zgodnie z która powód niedoskonałego funkcjonowania jednego rynku może wynikać z przeszkód w ciagłym i natychmiastowym oczyszczaniu innego rynku. Aby uchwycić współzależności zagregowanego popytu i zagregowanej podaży, odrzucił on perspektywę mikro, koncentrując się na badaniu wielkości makroekonomicznych.

${ }^{15}$ H. Bohn, G. Gorton, Coordination Failure, Multiple Equilibria and Economic Institutions, „Economica” 60, 1993, nr 239.

${ }^{16}$ K. Mischel, Sticky Prices as a Coordination Success, „Atlantic Economic Journal” 26, 1998, nr 2.

${ }^{17}$ Oczywiście, sa również takie modele niecenowych błędów koordynacji, jak choćby konstrukcja G. Wogloma, które zawężaja analizę do przypadku jednego rynku, stosując metodę równowag cząstkowych.

${ }^{18}$ M. Weitzman, op. cit. 
Podczas gdy przedstawiciele keynesizmu nierównowagi ${ }^{19}$ oraz modeli racjonowania ${ }^{20}$ kontynuowali badanie zjawiska fluktuacji gospodarczych $\mathrm{z}$ wykorzystaniem ram równowagi ogólnej, większość neokeynesistów porzuciła takie podejście na rzecz - mniej realistycznej i przydatnej z praktycznego punktu widzenia, ale znacznie łatwiejszej - metody równowag cząstkowych. W tego typu konstrukcjach teoretycznych uwaga skupia się na określonych frykcjach w obrębie wyłącznie jednego rynku (pracy, dóbr lub finansów), przy założeniu implicite, że pozostałe rynki działaja w sposób doskonały. Zaletą neokeynesowskich modeli niecenowych błędów koordynacji jest powrót do metody zaproponowanej pierwotnie przez J. M. Keynesa, która umożliwia obserwację zarówno kanałów transmisji szoków od jednego rynku do drugiego, jak i analizę konsekwencji niedoskonałości dotykających wybranego odcinka działalności gospodarczej dla funkcjonowania całego systemu. Cennym rozwinięciem idei współzależności zagregowanej podaży i zagregowanego popytu, zaoferowanym przez modele błędów koordynacji, stały się natomiast solidne, wysoce sformalizowane podstawy mikroekonomiczne, których wyraźnie brakowało w Ogólnej teorii.

Modele niecenowych błędów koordynacji nawiązują też do poglądów J. M. Keynesa w kwestii roli, jaką dla wahań koniunktury odgrywają oczekiwania i stan zaufania społeczeństwa. Chociaż modele wielorakiej równowagi sa oparte na odmiennych podstawach formalnych (strukturze walrasowskiej), to wzorem J. M. Keynesa uzależniaja proces dochodzenia do stanu stabilnego od prognoz gospodarczych ${ }^{21}$. W rezultacie system może utknąc $\mathrm{w}$ jednej z wielu równowag różniących się między sobą stopniem wykorzystania czynników produkcji. J. M. Keynes ${ }^{22}$ był przekonany o tym, że istnieje wiele możliwych stanów równowagi, a osiągnięcie jednego z nich odznaczającego się określonymi wskaźnikami gospodarczymi jest zdeterminowane oczekiwaniami ${ }^{23}$. Według J. M. Keynesa, wielkości bieżące można stosować jedynie w stanach statycznych, natomiast dynamiczny proces dochodzenia do równowagi wymaga ,[...] bezpośredniego uwzględniania znaczenia, jakie przyszłość ma dla [...] analizy aktualnie istniejącej równowagi" ${ }^{24}$. Oparcie całego wywodu na wielkościach oczekiwanych było jedna z tych cech, które zadecydowały o rewolucyjnym charakterze Ogólnej teorii. O związku między wahaniami poziomu aktywności gospodarczej a prognozami J. M. Keynes pisał następująco: „Brak stabilności [...] należy [...] przypisać pewnym cechom natury ludzkiej, które sprawiają, że nasze działania - czy to w sferze moralności, czy zaspokajania potrzeb, czy gospodarki - w znacznej mierze zależą raczej od spontanicznego

${ }^{19}$ R. W. Clower, The Keynesian Counterrevolution: A Theoretical Appraisal, w: F. H. Hahn, F. P. R. Brechling (red.), The Theory of Interest Rates, Macmillan \& Co. Ltd., London 1965; A. Leijonhufvud, On Keynesian Economics and the Economics of Keynes. A Study in Monetary Theory, Oxford University Press, London 1968.

${ }^{20}$ R. J. Barro, H. L. Grossman, A General Disequilibrium Model of Income and Employment, „American Economic Review” 61, 1971, nr 1; E. Malinvaud, The Theory of Unemployment Reconsidered, Basil Blackwell, Oxford 1977.

${ }^{21}$ D. Colander, The New, the Neo, and New-Neo, „Methodus” 4, 1992, nr 1.

22 J. M. Keynes, wyd. pol., op. cit, s. 5.

${ }^{23}$ Ibidem, rozdz. 5.

${ }^{24}$ Ibidem, s. 128. 
optymizmu niż od nadziei matematycznej. Prawdopodobnie większość naszych decyzji zdziałania czegoś pozytywnego, których pełne konsekwencje rozciagna się na wiele dni, można rozpatrywać jedynie jako wynik zwierzęcych instynktów, jako wrodzony człowiekowi pęd do czynu zamiast trwania w bezwładzie, a nie jako średnią ważona ilościowo wyrażonych korzyści mnożonych przez ilościowo wyrażone prawdopodobieństwa. Przedsiębiorca tylko udaje przed samym sobą, jakoby powodowało nim głównie to, co stwierdza w swym prospekcie, jakkolwiek skrupulatnie byłby on sporządzony. Działalność jego opiera się na ścisłej kalkulacji przyszłych korzyści w stopniu niewiele większym niż wyprawa na biegun południowy. Wobec tego gdy zwierzęce instynkty sa przytłumione, a spontaniczny optymizm zawodzi, pozostawiając nas na łasce nadziei matematycznej, przedsiębiorczość więdnie i zamiera, przy czym obawy strat moga opierać się na przesłankach tak samo irracjonalnych, jak przedtem nadzieje na zyski”" ${ }^{25}$.

W Ogólnej teorii załamanie gospodarcze następuje dlatego, że - wobec chwiejności podstaw przewidywań oraz ich gwałtownych zmian - nagle pojawiają się wątpliwości, czy przewidywany zysk jest osiągalny. A kiedy takie wątpliwości raz się pojawia, bardzo szybko rozprzestrzeniają się na całe koła gospodarcze. Ogólny spadek nastrojów decyduje o ustaleniu równowagi Pareto-podrzędnej z niskimi poziomami inwestycji, produkcji, konsumpcji, dochodu i zatrudnienia. Z drugiej strony, powszechny optymizm inwestorów gwarantuje ożywienie gospodarcze i przesunięcie systemu w kierunku stabilnego stanu z pełnym wykorzystaniem czynników produkcji. Modele błędów koordynacji kontynuują tę myśl, dowodząc, że fluktuacje wielkości realnych i równowaga podrzędna mogą wystapić nawet wtedy, gdy każdy podmiot formuje swe oczekiwania w sposób racjonalny.

W modelach wielorakiej równowagi wykazano również, że wahania zmiennych realnych nie są w żaden sposób uzależnione od stopnia elastyczności cen i płac nominalnych. Błędy koordynacji są nieodłącznym elementem każdej zdecentralizowanej gospodarki, nawet wtedy gdy ceny i płace nominalne sa doskonale giętkie (a czasami właśnie dlatego, że są giętkie). Równowaga Pareto-podrzędna może być w pełni zgodna z racjonalnościa oczekiwań i prawidłowo funkcjonującym mechanizmem cenowo-płacowym. W gorszej równowadze obniżanie cen i płac jest bezcelowe, gdyż problemem nie sa nieprawidłowe ich poziomy, lecz trudności z taką synchronizacją wszystkich działań, by udało się pokonać pesymistyczne oczekiwania względem zmiennych niecenowych. Takie ujęcie problemu koordynacji, jako niewalrasowskiej wielorakiej równowagi, jest spójne z wizja J. M. Keynesa, według którego, aby zrozumieć fenomen depresji, należało wyjść znacznie dalej poza kwestię dostosowań cen i płac ${ }^{26}$. Chociaż wiele modeli keynesowskich - zarówno tych powojennych, jak i współczesnych - upatruje przyczyn spadków koniunktury w sztywnościach nominalnych, to faktem jest, że dla J. M. Keynesa bariery $\mathrm{w}$ dostosowaniach cenowo-płacowych nie miały znaczenia dla pojawiania się

\footnotetext{
${ }^{25}$ Ibidem, s. 142.

${ }^{26}$ P. Howitt, Coordination Failures, w: B. Snowdon, H. R. Vane (red.), An Encyclopedia of Macroeconomics, Edward Elgar, Cheltenham 2002.
} 
stanów depresji. Pisał on wyraźnie, że ,„[... istota argumentacji jest zupełnie niezależna od tego, czy płace nominalne itd. ulegają zmianie, czy nie" ${ }^{27}$. Zakładając w modelu doskonałą elastyczność cen, dowodził wprost, że sztywność płac nominalnych jest zdecydowanie bardziej korzystna od polityki giętkich płac, łatwo reagujących na zmiany rozmiarów bezrobocia ${ }^{28}$. Taką samą argumentację można odnaleźć w modelach błędów koordynacji, w których równowaga ze sztywnościami nominalnymi okazuje się Pareto-nadrzędna względem równowagi z proporcjonalnymi dostosowaniami cenowo-płacowymi. Oczywiście, J. M. Keynes nie przeczył istnieniu w gospodarkach rynkowych zjawiska usztywniania płac nominalnych, ale nie utożsamiał ich ze źródłem kryzysu. Fundamentalnym problemem dla niego był bowiem niedostatek popytu efektywnego na rynku dóbr i rozprzestrzenianie się jego ujemnych skutków na wszystkie pozostałe sektory.

J. M. Keynes zauważał, że sztywność nominalna płac wynika $\mathrm{z}$ walki pracowników o utrzymanie stałości ich względnej płacy realnej: ,,[...] każda jednostka lub grupa zgadzająca się na obniżkę płac nominalnych w stosunku do innych odczuje względna obniżkę płacy realnej, co jest dostatecznym powodem, by się tej obniżce opierać" ${ }^{29}$. W ten sposób pokazywał, że sztywności nominalne de facto prowadzą do pojawienia się na zdecentralizowanym rynku sztywności realnych. Także w neokeynesowskich modelach błędów koordynacji podkreśla się, że immanentnym elementem gospodarki rynkowej z defektem koordynacji są sztywności realne. E. Alvi na przykład dowiódł, że silna strategiczna komplementarność wymaga wysokiego stopnia realnej sztywności ${ }^{30}$. W sytuacji poważnej strategicznej komplementarności zmiana cen wprowadzona przez niektóre tylko firmy oznacza, że pozostali przedsiębiorcy muszą postąpić identycznie. To prowadzi do znaczących realnych sztywności cenowych. Natomiast kiedy strategiczna komplementarność jest słaba, ceny relatywne będą bardziej giętkie. Również R. C. Allen i J. H. Stone wykazali, że w gospodarce, w której produkcja jest zdominowana przez błędy koordynacji i strategiczną komplementarność, cenotwórcy będą dążyć do utrzymywania sztywnych cen relatywnych. Elastyczność cenowa będzie bowiem przynosić straty przedsiębiorcy, który zdecyduje się na przeprowadzenie dostosowań ${ }^{31}$.

Kolejną cechą łącząca modele wielorakiej równowagi ze stanowiskiem J. M. Keynesa jest to, że dowodzą one braku analogii między problemami na szczeblu mikro- a makroekonomicznym. Z neokeynesowskich modeli błędów koordynacji płynie wniosek, że koncepcja jedynej równowagi, w której synchronizacja indywidualnych działań jest doskonała, a optymalny rezultat społeczny nie różni się od optymalności na szczeblu jednostki, jest fikcją ${ }^{32}$. Tego samego

${ }^{27}$ J. M. Keynes, wyd. pol., op. cit., s. 26.

${ }^{28}$ Ibidem, rozdz. 19.

${ }^{29}$ Ibidem, s. 14-15.

${ }^{30}$ E. Alvi, Strategic Interactions and Real Rigidity - Complementarity between Two Keynesian Concepts, „Southern Economic Journal” 59, 1993, nr 3.

${ }^{31}$ R. C. Allen, J. H. Stone, Strategic Behavior, Real Rigidities, and Production Coordination Failures, „Eastern Economic Journal” 27, 2001, nr 3.

${ }^{32}$ H. van Ees, H. Garretsen, On the Contribution of New Keynesian Economics, „Eastern Economic Journal" 18, 1992, nr 4. 
zdania był J. M. Keynes, dla którego zależności obserwowane na poziomie indywidualnych wyborów nie mogły być traktowane jako wyznacznik zachowania całego systemu, dlatego nade wszystko interesował się analizą makroekonomiczną, która pozwoliła mu odrzucić redukcjonizm, a tym samym zanegować prawo rynków Saya. W modelu Keynesa decyzje, które są racjonalne z punktu widzenia pojedynczego podmiotu (na przykład zwiększenie oszczędności z przyczyn przezornościowych), moga poprzez proces mnożnikowy wywołać trwałe negatywne konsekwencje w skali zagregowanej (nadprodukcja i przymusowe bezrobocie), nabierając cech nieracjonalności. Neokeynesowskie modele błędów koordynacji przywracaja ten dualny charakter procesu mnożnikowego, i to nie w sposób mechaniczny, ale za pomocą psychologicznego zjawiska wahań nastrojów społecznych ${ }^{33}$.

Związek między poglądami J. M. Keynesa a neokeynesowskimi modelami błędów koordynacji wyraża się również w tym, że te ostatnie dostarczają makropodstaw mikroekonomii ${ }^{34}$. Problem makroekonomiczny w postaci równowagi Pareto-podrzędnej można zrozumieć wyłącznie analizując wybory jednostek w pewnym kontekście instytucjonalnym. Konkretna równowaga jest zdeterminowana oczekiwaniami formowanymi w stricte określonym otoczeniu. Instytucje odgrywają tu dwie role: koordynują prognozy podmiotów co do decyzji pozostałych uczestników rynku oraz koordynuja działania podmiotów przy danym stanie prognoz. Większość ekonomistów - czy to nowoklasycznych, czy neokeynesowskich - koncentruje się na drugiej $\mathrm{z}$ tych ról, sugerując, że doskonale elastyczne ceny rynkowe zapewnią optymalna synchronizację indywidualnych wyborów. $\mathrm{Z}$ modeli błędów koordynacji natomiast można wywnioskować, że to istniejąca struktura instytucjonalna doprowadza do ustalenia danej równowagi gospodarczej. Płaszczyzna instytucjonalna staje się centralnym zagadnieniem dla badań makroekonomicznych. W ten sposób ekonomii keynesowskiej przywraca się jej znaczenie jako teorii ogólnej, dopuszczającej wielość możliwych równowag, a ekonomia klasyczna nabiera cech przypadku szczególnego, wynikającego - po nałożeniu odpowiednich założeń dotyczących instytucji - z teorii keynesowskiej.

\section{ANTYKEYNESOWSKI WYDŹWIEடK NIECENOWYCH MODELI BŁĘDÓW KOORDYNACJI}

Neokeynesowskie modele niecenowych błędów koordynacji, obok cech świadczących o ich silnych związkach z paradygmatem keynesowskim, posiadają również takie własności, które pozwalaja na zakwestionowanie ich keynesowskiej proweniencji. Najpoważniejszym zarzutem pod ich adresem jest to, że generując nieskończenie wiele potencjalnych równowag, nie dają podstaw do określenia, który i czy w ogóle jakikolwiek stan stabilny zostanie ostatecznie osiagnnięty ${ }^{35}$. Podmioty podejmuja tu decyzje na zasadzie losowej, kierując się

${ }^{33}$ D. Colander, op. cit.

${ }^{34}$ Idem, New Keynesian Economics in Perspective, „Eastern Economic Journal” 18, 1992, nr 4.

${ }^{35}$ P. Howitt, op. cit. 
realizacją różnych zmiennych przypadkowych, przez co nie można ocenić nawet ilościowo - stopnia i kierunku reakcji gospodarki na wahania wielkości egzogenicznych, w tym instrumentów polityki. W obliczu takich wahań system przesuwa się od jednej równowagi do drugiej i nie można jednoznacznie stwierdzić, że dana sytuacja będzie prowadzić do stanu stabilnego z określonymi wskaźnikami gospodarczymi. Brak przesłanek do precyzyjnego wyznaczenia ścieżki reakcji systemu sprawia, że w tych modelach każdy wynik jest tak samo możliwy do wystąpienia. Co więcej, każdy rezultat nabiera cech równowagi. Sytuacja, w której wszystko może się wydarzyć, rodzi nie tylko pytanie o to, w jaki sposób można model odrzucić, ale także uzasadniona wątpliwość, czy w ogóle można go odrzucić. Pozbawia to konstrukcję teoretyczną jakiejkolwiek treści empirycznej ${ }^{36}$. Ograniczenie liczby możliwych do osiągnięcia równowag, a tym samym nadanie modelowi większej precyzji, wymagałoby wprowadzenia szeregu założeń instytucjonalnych. Po pierwsze jednak miałyby one typowy charakter ad hoc, a po drugie musiałyby być bardzo liczne i skomplikowane. Stąd modele błędów koordynacji oferuja niewiele wskazówek co do sfery instytucjonalnej, pozostawiając otwartą kwestię tego, która $\mathrm{z}$ równowag wystąpi $\mathrm{z}$ większym prawdopodobieństwem ${ }^{37}$. W efekcie często uznaje się je za niekompletne i niespójne z paradygmatem keynesowskim.

Z powyższym zarzutem wiąże się kolejny problem polegający na tym, że mimo iż modele wielorakiej równowagi ilustrują pewien rodzaj błędu koordynacji, to faktycznie pomijaja cała analizę procesu synchronizacji pojedynczych działań w skali makroekonomicznej ${ }^{38}$. Sugeruje się w nich jedynie, że brak założenia doskonałej koordynacji może prowadzić do takiego procesu wymiany, którego rezultaty nie będą efektywne. Pytanie, w jaki sposób dochodzi do ustalenia danej równowagi, pozostaje natomiast bez odpowiedzi. Przyjmuje się tu po prostu, iż pojedynczy podmiot zdaje sobie sprawę z tego, że wszyscy pozostali uczestnicy rynku posiadają wiedzę na temat tego, która równowaga została faktycznie wybrana. W ten sposób ignoruje się skomplikowany proces wyboru i dochodzenia do równowagi, zakładając ad hoc doskonałą znajomość przez podmioty struktury modelu.

Kolejną antykeynesowską cechą modeli niecenowych błędów koordynacji jest koncentracja na realnej stronie gospodarki. Istnienie strategicznej komplementarności i wielorakiej równowagi nie jest w żaden sposób uzależnione od obecności pieniądza ${ }^{39}$. Defekt koordynacji może się pojawić nawet w sytuacji doskonałej elastyczności cenowo-płacowej, implikując tym samym brak wpływu pieniądza na wielkości realne. Rola pieniądza sprowadza się tu jedynie do kształtowania oczekiwań podmiotów co do warunków gospodarowania, sygnalizowania społeczeństwu intencji władz monetarnych i rządowych. Nie jest to zatem dający się określić ilościowo bezpośredni efekt wywierany na zmienne realne, lecz jedynie wpływ pośredni, którego rezultat końcowy - na mocy

${ }^{36}$ J. J. Rotemberg, The New Keynesian Microfoundations, w: S. Fischer (red.), NBER Macroeconomics Annual, MIT Press, Cambridge, Massachusetts, 1987.

${ }^{37}$ D. Colander, New Keynesian Economics in Perspective, op. cit.

${ }^{38}$ H. van Ees, H. Garretsen, op. cit.

39 Ibidem. 
wspomnianej wyżej konstrukcji omawianych modeli - nie jest precyzyjnie określony. Pożądana reakcja podmiotów na bodziec monetarny, czyli przesunięcie systemu z równowagi Pareto-podrzędnej do Pareto-nadrzędnej, wymaga przyjęcia wielu założeń odnoszących się do struktury instytucjonalnej i zachowań indywidualnych, czego w modelach wielorakiej równowagi się nie czyni. Zakłada się $\mathrm{w}$ nich jedynie implicite, że podmiot dowie się, w jaki sposób pieniądz wpłynie na produkcję i zatrudnienie dopiero wtedy, gdy dana równowaga zostanie faktycznie ustalona ${ }^{40}$.

Takie podejście jest sprzeczne ze stanowiskiem J. M. Keynesa i tradycyjnie pojmowana istota paradygmatu keynesowskiego, w którym pieniądz odgrywa kluczową bezpośrednią rolę $\mathrm{w}$ kształtowaniu wielkości realnych. Pisał on bowiem wyraźnie: „Pieniądz, jeśli chodzi o jego najważniejsze właściwości, stanowi przede wszystkim subtelny środek wiązania teraźniejszości z przyszłością i bez wprowadzenia pojęć pieniężnych nie możemy nawet zacząć rozważać, jakie skutki ma zmiana przewidywań dla bieżącej działalności” ${ }^{41}$. W Ogólnej teorii pieniądz mógł pobudzić aktywność gospodarczą poprzez obniżkę stopy procentowej, dzięki czemu rosły inwestycje, produkcja, zatrudnienie, konsumpcja i dochód. Władze monetarne mogły więc - zwiększając spread między kosztem pożyczki a krańcową rentownością kapitału - wpłynąć na prywatne inwestycje i uruchomić proces mnożnikowy prowadzacy do ogólnego ożywienia. Równocześnie przestrzegał przed nazbyt gwałtownymi i niezapowiedzianymi decyzjami banku centralnego, które mogłyby zwiększyć niepewność społeczeństwa co do intencji władz i faktycznych warunków gospodarowania. Podmioty, kierując się motywem przezornościowym, zgłosiłyby wtedy na tyle wysoki popyt na pieniądz, że pojawiłaby się realna groźba nadprodukcji i spadku stanu zaufania, pogłębiającego jeszcze bardziej spowolnienie gospodarcze.

Zdaniem D. Romera ${ }^{42}$, problem braku wpływu pieniądza na sferę realną w neokeynesowskich modelach wielorakiej równowagi wynika z tego, że próbuje się w nich wyjaśniać fluktuacje gospodarcze wyłącznie na podstawie błędów koordynacji, bez jakichkolwiek odwołań do barier w dostosowaniach cenowych. W jego opinii, aby móc przeanalizować kluczowy dla wszystkich keynesistów problem wpływu szoków monetarnych i innych zakłóceń zagregowanego popytu na zmiany aktywności gospodarczej, należy wprowadzić element niedoskonałej elastyczności cen i płac. W wypadku kiedy ceny i płace nominalne moga reagować natychmiast i wprost proporcjonalnie, zakłócenia nominalne zawsze będą pozostawiać sektor realny bez zmian.

Pogląd D. Romera nie wydaje się jednak słuszny. W tej kwestii rację należy przyznać raczej P. Davidsonowi ${ }^{43}$, który utrzymywał, że dyskusja o stopniu konkurencji czy giętkości cen i płac nie ma nic wspólnego z istotą teorii Keynesa, która znajduje zastosowanie do każdego przypadku. Z tego względu, że J. M. Keynes rozpatrzył również sytuację konkurencyjnego rynku z doskonale elastycznymi cenami i płacami, negując tym samym tezę, jakoby sztywności były warunkiem koniecznym lub wystarczającym do pojawienia się równowagi

\footnotetext{
40 J. J. Rotemberg, op. cit.

${ }^{41}$ J. M. Keynes, wyd. pol., op. cit., s. 267.

${ }^{42}$ D. Romer, The New Keynesian Synthesis, ,Journal of Economic Perspectives” 7, 1993, nr 1.

${ }^{43}$ P. Davidson, Would Keynes Be a New Keynesian?, „Eastern Economic Journal” 18, 1992, nr 4.
} 
z niepełnym wykorzystaniem czynników produkcji ${ }^{44}$. Pełna elastyczność cenowo-płacowa nie gwarantuje ciagłego i natychmiastowego oczyszczania się rynku, gdyż fundamentalną przyczyną wahań gospodarczych jest istnienie pieniądza. Gdyby było inaczej to, zdaniem P. Davidsona, zalecenia polityczne J. M. Keynesa odnosiłyby się do sposobów eliminacji błędów rynkowych stojących na przeszkodzie pełnej giętkości cen i płac, a nie skupiały na naturze przedsiębiorczości w gospodarce pieniężnej, w której niedostateczny popyt efektywny jest jedyną przeszkodą do osiągnięcia najlepszej równowagi. Ten właśnie pogląd wydaje się najwierniej oddawać intencje J. M. Keynesa. Stąd należy uznać, że problemem tkwiącym w neokeynesowskich modelach wielorakiej równowagi nie jest brak ograniczeń narzucanych na dostosowania cenowo-płacowe, lecz niesatysfakcjonujące uwzględnienie roli pieniądza jako czynnika aktywnie kształtującego zmienne realne.

\section{ZAKOŃCZENIE}

Omówione modele niecenowych błędów koordynacji stanowią jeden z ważniejszych obszarów neokeynesowskiego programu badawczego. Przejawiaja one liczne cechy, jednoznacznie wskazujące na ich keynesowski rodowód. Za ich niewątpliwą zaletę uznaje się to, że przywracają wiele z kluczowych aspektów Ogólnej teorii, których znaczenie w toku dynamicznej ewolucji myśli keynesowskiej zostało źle odczytane, wypaczone lub po prostu całkowicie pominięte. Równie często wskazuje się jednak, że ich keynesowska proweniencja jest wysoce dyskusyjna. Posiadaja one bowiem również i takie atrybuty, które stoją w wyraźnej sprzeczności z intencjami J. M. Keynesa i tradycyjnie pojmowanymi fundamentami paradygmatu keynesowskiego. Neokeynesowskie modele niecenowych defektów koordynacji są więc przykładem konstrukcji o bardzo niejednoznacznej naturze, które łączą w sobie elementy niejednorodne pod względem ich „keynesowskiej ortodoksyjności”.

Spory wokół omawianych modeli toczące się w literaturze przedmiotu nie przyniosły odpowiedzi na pytanie o ich treść i znaczenie dla rozwoju myśli keynesowskiej. Podczas gdy na przykład H. van Ees i H. Garretsen ${ }^{45}$ oraz D. Colander ${ }^{46}$ uznali niecenowe błędy koordynacji za trzon całego paradygmatu, P. Davidson ${ }^{47}$, J. Silvestre ${ }^{48}$ czy D. Romer ${ }^{49}$ określili je mianem antykeynesowskich. Co ciekawe, D. Romer, sugerując całkowite wykluczenie problematyki niecenowych defektów synchronizacji z obszaru badań keynesowskich, w tej samej publikacji zaliczył model efektów zewnętrznych „tłustych” rynków P. A. Diamonda do jednej z czołowych neokeynesowskich teorii sztywności realnych cen. Natomiast J. J. Rotemberg ${ }^{50}$, bardzo krytycznie nastawiony do omawianych modeli, przyznawał, że część zarzutów kierowanych

\footnotetext{
44 J. M. Keynes, op. cit., rozdz. 19.

${ }^{45}$ H. van Ees, H. Garretsen, op. cit.

${ }^{46}$ D. Colander, New Keynesian Economics in Perspective, op. cit.

47 P. Davidson, op. cit.

${ }^{48}$ J. Silvestre, op. cit.

${ }^{49}$ D. Romer, op. cit.

50 J. J. Rotemberg, op. cit.
} 
pod ich adresem równie dobrze można odnieść do modeli sztywności nominalnych ${ }^{51}$ cen, które są powszechnie traktowane jako kwintesencja keynesizmu. Uwaga ta dotyczy w głównej mierze zarzutu, zgodnie z którym modele niecenowych defektów synchronizacji, prowadząc do wielorakiej równowagi, nie dostarczaja podstaw do określenia, którą z nich system faktycznie osiagnie. J. J. Rotemberg wskazywał, że taka sama wątpliwość odznacza konstrukcje nieelastyczności nominalnych cen, w których pojawia się szereg równowag o odmiennym stopniu giętkości cen i znacząco różnych walorach jakościowych. W niektórych sytuacjach zmiany poziomu cen maja bowiem charakter łagodny i stopniowy, a w innych dochodzi do zmian nagłych i skokowych, co nie pozostaje bez wpływu na bieżące i przyszłe zachowanie uczestników rynku. Podobnie jak w wypadku kwestionowanych modeli błędów koordynacji w sferze realnej, również modele sztywności nominalnych cen nie dostarczają wytłumaczenia, która równowaga faktycznie zostanie ustalona.

Ostateczne rozstrzygnięcie problemu dotyczącego „keynesowskiego” charakteru modeli niecenowych błędów koordynacji wydaje się zatem nader odległe. Być może rację miał N. G. Mankiw ${ }^{52}$, który stwierdził, że pomimo swego niezaprzeczalnego wkładu, Ogólna teoria jest książka niejasną i mało zrozumiałą, budzącą wątpliwości, czy sam J. M. Keynes był w pełni świadom wagi i znaczenia wszystkich aspektów zaproponowanej przez siebie wizji świata, a nadrzędnym celem neokeynesistów z kolei jest zgłębienie zasad funkcjonowania systemu rynkowego, nie eksplanacja poglądów jednego człowieka. Stąd według N. G. Mankiwa, jeśli współczesny keynesizm nie oddaje w pełni intencji J. M. Keynesa wyrażonych wiele dziesięcioleci temu, tym gorzej dla Keynesa.

dr hab. Izabela Bludnik

Profesor Uniwersytetu Ekonomicznego w Poznaniu

izabela.bludnik@ue.poznan.pl

\title{
MULTIPLE EQUILIBRIA IN THE NEW KEYNESIAN MODELS OF NON-PRICE COORDINATION FAILURES
}

\section{Summary}

\begin{abstract}
The possibility of multiple equilibria that may be ranked subject to the level of underemployment is one of the most important New Keynesian research field. A failure in coordinating all the individual decisions made by rational agents at the aggregate level is treated as a crucial cause of multiple equilibria. There are two main New Keynesian scopes concerning the malfunctioning of unanimous actions. One links the coordination failures entirely to the lack of correct nominal price adjustments in the face of disturbances. The other one focuses on synchronisation problems in the real sector (production and trade). While the former is commonly perceived as a core of Keynesian paradigm, the latter is of a very controversial character. The aim of the paper is to analyse the crux of New Keynesian non-price coordination failure models. The paper contains arguments that confirm their Keynesian origin and allow, at the same time an exclusion from the Keynesian scientific agenda.
\end{abstract}

${ }^{51}$ G. A. Akerlof, J. L. Yellen, op. cit.; N. G. Mankiw, op. cit.; O. J. Blanchard, N. Kiyotaki, op. cit.

${ }^{52}$ N. G. Mankiw, The Reincarnation of Keynesian Economics, w: B. Snowdon, H. R. Vane (red.), A Macroeconomics Reader, Routledge, New York 1997, s. 446. 
